\title{
Ion-molecule reactions of $\mathrm{CoAr}_{6}^{+}$with nitrogen oxides $\mathrm{N}_{2} \mathrm{O}, \mathrm{NO}$, and $\mathrm{NO}_{2}$ : measuring absolute pressure by shock-freezing of the collision complex
}

\author{
C. van der Linde, R.F. Höckendorf, O.P. Balaj, and M.K. Beyer \\ Institut für Physikalische Chemie, Christian-Albrechts-Universität zu Kiel, \\ Olshausenstraße 40, 24098 Kiel, Germany \\ E-mail: beyer@phc.uni-kiel.de
}

Received December 16, 2009, revised January 12, 2010

\begin{abstract}
A new method to determine the absolute pressure in an ultra-high vacuum apparatus is tested using ion molecule reactions with $\mathrm{CoAr}_{6}^{+}$. In a collision with a neutral reactant, the complex between $\mathrm{Co}^{+}$and the collision partner is stabilized by evaporation of argon atoms. If $\mathrm{CoAr}_{6}^{+}$reacts with collision rate, the absolute pressure can be determined by comparing the experimental collision rate with the collision rate calculated from average dipole orientation theory. The experimental results with $\mathrm{N}_{2} \mathrm{O}, \mathrm{NO}$ and $\mathrm{NO}_{2}$ indeed show that the collision complex is frozen out. Comparison of the rates of primary, secondary and tertiary reaction products, however, suggests that not all collisions of $\mathrm{CoAr}_{6}^{+}$are reactive.
\end{abstract}

PACS: $82.30 . F i \quad$ Ion-molecule, ion-ion, and charge-transfer reactions.

Keywords: FT-ICR mass spectrometry, pressure calibration, chemical kinetics, $\mathrm{CoAr}_{6}^{+}$cluster, nitrogen oxides, Ar-matrix, collision theory.

\section{Introduction}

Ionization gauges are widely used as pressure measuring devices in the low pressure range [1-4]. Fourier transform ion cyclotron resonance mass spectrometry (FT-ICRMS) is a well suited tool to investigate bimolecular cluster ion-molecule reactions [5-20]. In order to determine absolute rate constants one should know the absolute pressure in the ICR-cell accurately, because the pressure is the main uncertainty. Ionization gauge readings depend on the particular gas. In the region of $10^{-10}-10^{-7}$ mbar, measuring absolute pressure is not a trivial task. Different ionization probabilities have an effect on the reading, but it also depends on the gauge voltage, geometry and several other instrumental effects $[3,13,21,22]$. Standard ionization gauges are calibrated against nitrogen $[1,4,23]$. The gauge sensitivity can vary with a factor of 30 compared to helium [2].

The gauge sensitivity, however, is not the only effect that makes the determination of absolute pressures inside the ICR cell difficult. Equally important is the geometry of the vacuum chamber, in particular the relative position of the ICR cell, the ion gauge and the turbomolecular pump, which can be accounted for with an instrument-specific geometry factor $[13,22]$. The geometry factor does not account for the different pumping efficiency of gases with high sticking coefficients. It is not self-evident how the sticking probability influences the pressure reading. However, it is quite obvious that, if one extrapolates to the base pressure, the absolute pressure in the cell depends largely on the amount of water in the ultra-high vacuum (UHV) region, which is only weakly correlated to the reading of the ion gauge.

The ideal pressure measurement requires introducing the sensor directly into the ICR cell. As a sensor, we use here $\mathrm{CoAr}_{6}^{+}$, which can be viewed as a cryogenic nanomatrix. We expect this ion to react, with collision rate, with polar molecules, since exchange of an Ar atom against a polar or strongly polarizable molecule will be exothermic and face a small barrier. $\mathrm{CoAr}_{6}^{+}$is known to have octahedral symmetry [24,25], and its collision rate with neutral molecules should be well described with average dipole orientation (ADO) theory [26-30], a modification of Langevin collision theory [31] which includes the effect of a permanent dipole moment. Other candidates as pressure sensor ion are $\mathrm{Ar}_{2} \mathrm{H}^{+}$or $\mathrm{Ar}_{3} \mathrm{H}_{3}^{+}$[32-35]. For those species, however, the ion signal from our laser vaporization is less 
stable than with $\mathrm{CoAr}_{6}^{+}$, which would make routine application of the method difficult.

In the present work, we test this approach on the pressure measurement of $\mathrm{N}_{2} \mathrm{O}$, $\mathrm{NO}$ and $\mathrm{NO}_{2}$. The reaction pathways are analyzed in detail, and the validity of the initial assumptions is discussed.

\section{Experimental setup}

The experiments were performed on a modified Bruker Spectrospin CMS47X mass spectrometer [36-38]. In the new setup in Kiel it is equipped with a $4.7 \mathrm{~T}$ unshielded superconducting magnet, an APEX III data station, a Bruker infinity cell, TOPPS ion optics power supply, and an ICC2 Infinity Cell Controller with $\mathrm{BCH}$ preamplifier. The pressure in the cell region is measured by a shielded IKR020 cold cathode. Ions were produced in an external laser vaporization source [39-41]. The $\mathrm{CoAr}_{6}^{+}$clusters were produced by laser vaporization of a solid cobalt target disk by a frequency doubled Nd:YAG laser $(532 \mathrm{~nm})$. The vaporization laser and frequency doubling crystal were heated by 20 laser shots, followed by 20 shots $(10 \mathrm{~Hz}$, $5 \mathrm{~mJ}$ pulse energy) to fill the ICR-cell and guarantee stable experimental conditions. The metal plasma was entrained in a $50 \mu$ s pulse of argon at a pressure of 22 bar followed by supersonic expansion into high vacuum, which results in the formation of $\mathrm{CoAr}_{n}^{+}(n=1-6)$ clusters. The clusters were transferred by electrostatic lenses through several stages of differential pumping and stored in the ICR-cell. 20 cycles of laser vaporization were accumulated for each spectrum, and 20 mass spectra were averaged to get a decent signal-to-noise ratio. The $\mathrm{CoAr}_{6}^{+}$cluster was mass selected for the experiment by resonant ejection of unwanted ions. Reaction gases were introduced into the cell region via a needle valve to a constant pressure in the range of $5 \cdot 10^{-10}$ to $5 \cdot 10^{-8}$ mbar. To monitor the reaction, mass spectra after different reaction delays were taken. The reaction delay is measured relative to the end of the fill cycle and mass selection.

\section{Data analysis}

The proposed pressure calibration method requires an ion which reacts with collision rate with the neutral molecules of the gas. The octahedral $\mathrm{CoAr}_{6}^{+}$cluster should fulfill this condition because argon is a noble gas and only weakly bound to the central cobalt- $d^{8}$ cation. $\mathrm{CoAr}_{6}^{+}$has a filled first coordination shell, with the argon atoms sitting in the corners of a regular octahedron [24]. It is stable, the complex is the global minimum of the $\left[\mathrm{Co}, \mathrm{Ar}_{6}\right]^{+}$potential energy surface $[24,25,42]$. Important for our experimental conditions, it does not undergo black-body radiation induced dissociation [43-51], as evidenced in Fig. 1. After storing the mass selected ion for $10 \mathrm{~s}$ at a pressure below $10^{-10}$ mbar as read from the ion gauge, no fragment ions are observed. The peak at $m / z=99.7$ is the third harmonics

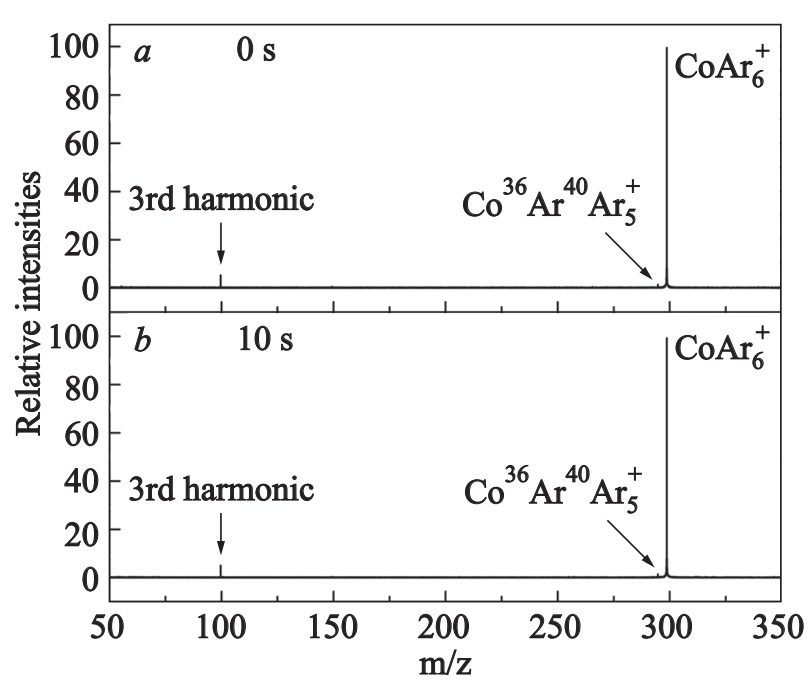

Fig. 1. Mass spectra of the isolated $\mathrm{CoAr}_{6}^{+}$cluster at $t=0 \mathrm{~s}(a)$ and $t=10 \mathrm{~s}(b)$ at a pressure below $10^{-10}$ mbar. No fragmentation induced by black-body radiation is observed.

of $\mathrm{CoAr}_{6}^{+}$, the peak at $m / z=295$ is $\mathrm{Co}^{36} \mathrm{Ar}^{40} \mathrm{Ar}_{5}^{+}$, its intensity matching the natural abundance of ${ }^{36} \mathrm{Ar}$.

Removal of an Ar atom from the cluster requires $10 \mathrm{~kJ} / \mathrm{mol}$, calculated with the B3LYP/SDD method in Gaussian 03 [52]. From the stability of $\mathrm{CoAr}_{6}^{+}$over very long times, we can conclude that the internal energy of the cluster lies below this value. In thermal equilibrium, an average internal energy of $10 \mathrm{~kJ} / \mathrm{mol}$ corresponds to a temperature of $125 \mathrm{~K}$, calculated from the calculated vibrational modes of $\mathrm{CoAr}_{6}^{+}$in the harmonic oscillator approximation. The clusters are most likely much colder than this value, since no dissociation is observed.

A widely used pressure calibration method for FT-ICRMS takes an empirical geometric factor $G$ and the chemical sensitivity $R_{x}$ of the gauge into account [21,22]. The chemical sensitivity $R_{x}$ depends on the polarizability $\alpha$ of the reactant molecules following the empirical relationship introduced by Bartmess and Georgiadis [2]:

$$
R_{x}=0.36 \alpha+0.30
$$

The pressure was corrected by Eq. (2) using the empirical geometry factor $G$ which has a value of $3.7 \pm 1.0$ for our setup:

$$
p_{x}^{\text {cell }}=\frac{G}{R_{x}} p_{x}^{\exp } .
$$

If the initial assumption is correct and $\mathrm{CoAr}_{6}^{+}$reacts with collision rate, the relative rate constants of the primary reaction channels sum up to the experimental collision rate $k_{\text {rel }} / \mathrm{s}^{-1}$. The relative rate constants are available by fitting the resulting time-intensity charts under the assumption of pseudo first order kinetics. This was done using a 
genetic algorithm as implemented in our data analysis software Analyzze 2.8.

The theoretical collision rate constant may be calculated using ADO theory. Average dipole orientation theory was introduced by Su and Bowers [28] and is based on classical trajectories of a linear dipole in the field of a point charge, as introduced by Langevin [31]. The collision rates were calculated using the HSA collision rates program [53]. Relative rate constants $k_{\text {rel }}$ are converted to absolute rate constants $k_{\text {abs }}$ with the following equation:

$$
k_{\mathrm{abs}}=\frac{k_{\mathrm{rel}} k_{B} T}{p_{x}^{\text {cell }}} .
$$

In this equation, $p_{x}^{\text {cell }}$ is the actual pressure, $k_{B}$ the Boltzmann constant, and $T$ the temperature of the collision gas. Measuring $k_{\text {rel }}$ and calculating $k_{\text {abs }}$ thus immediately yields $p_{x}^{\text {cell }}$. To transfer the results to other experiments and to investigate the pressure dependence of the deviation between measured and actual pressure, we introduce the correction factor $K_{p}$ :

$$
K_{p}=\frac{p_{x}^{\text {cell }}}{p_{x}^{\exp }} .
$$

Calculating $k_{\mathrm{abs}}$ from $\mathrm{ADO}$ theory requires the polarizability $\alpha$, the dipole moment $\mu_{D}$ and the dipole locking constant $c$, as introduced by Su and Bowers [28]. Dipole moments $\mu_{D}$ were calculated using the Gaussian 03 program on G3 level [52]. Polarizabilities $\alpha$ [54] and dipole locking constants $c$ [28] were taken from literature.

The new calibration method also takes into account that pressure correction may depend on the pressure range of the experiment and the physical and chemical behavior of the reactant gas, especially against the surfaces of the instrument, which range from stainless steel via gold-plated oxygen free copper to glass ceramics.

\section{Experimental results}

Figure 2 shows mass spectra of the reaction of $\mathrm{CoAr}_{6}^{+}$ with nitrogen oxide (NO) after $t=0 \mathrm{~s}(a)$ and $t=5 \mathrm{~s}(b)$. Because filling the cell takes about $2 \mathrm{~s}$, there are reaction products at nominal $t=0 \mathrm{~s}$. Three primary reactions were observed: On the one hand ligand exchange to yield $\mathrm{Co}(\mathrm{NO})^{+}$and $\mathrm{CoAr}(\mathrm{NO})^{+}$, and on the other hand loss of one argon atom resulting in $\mathrm{CoAr}_{5}^{+}$, while $\mathrm{Co}(\mathrm{NO})^{+}$is the main product of the reaction. The time-intensity chart is shown in Fig. 3. The deviations from the fit are the most likely due to pressure variations, keeping the NO pressure constant was very difficult. As shown above, black-body radiation is not responsible for losing argon atoms, so $\mathrm{CoAr}_{5}^{+}$must be the result of a collision with NO:

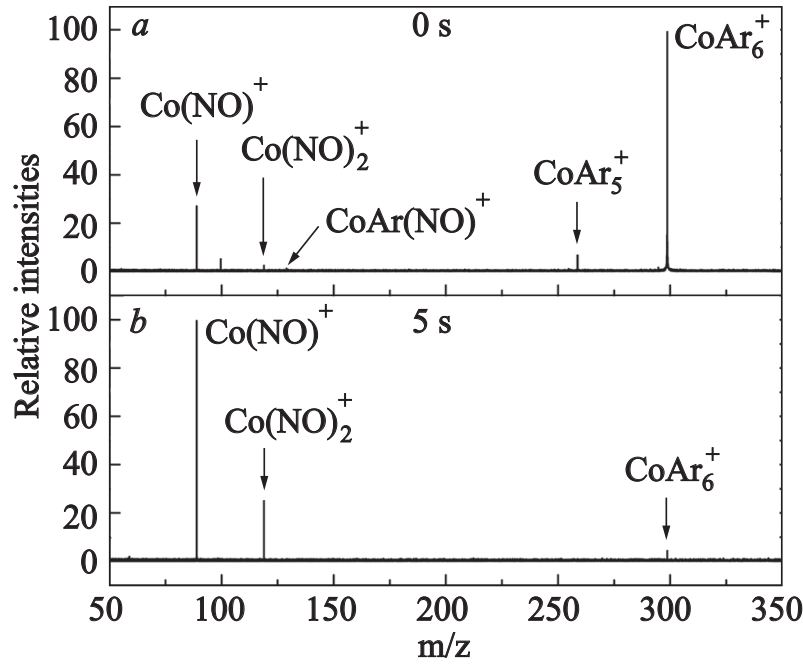

Fig. 2. Mass spectra of the reaction of $\mathrm{CoAr}_{6}^{+}$with $\mathrm{NO}$ after $t=0 \mathrm{~s}$ (a) and $t=5 \mathrm{~s}(b)$ at an experimental pressure of $3.9 \cdot 10^{-8}$ mbar.

$$
\begin{aligned}
& \mathrm{CoAr}_{n}^{+}+\mathrm{NO} \longrightarrow \mathrm{Co}(\mathrm{NO})^{+}+n \mathrm{Ar} ; n=5,6, \\
& \mathrm{CoAr}_{n}^{+}+\mathrm{NO} \longrightarrow \mathrm{CoAr}(\mathrm{NO})^{+}+(n-1) \mathrm{Ar} ; n=5,6, \\
& \mathrm{CoAr}_{6}^{+}+\mathrm{NO} \longrightarrow \mathrm{CoAr}_{5}^{+}+\mathrm{NO}+\mathrm{Ar} .
\end{aligned}
$$

The genetic algorithm suggests that $\mathrm{CoAr}(\mathrm{NO})^{+}$is exclusively formed from $\mathrm{CoAr}_{5}^{+}$. However, given the low intensity of both $\mathrm{CoAr}_{5}^{+}$and $\operatorname{CoAr}(\mathrm{NO})^{+}$, this is most likely a numerical artifact. $\mathrm{CoAr}(\mathrm{NO})^{+}$undergoes a second ligand exchange to $\mathrm{Co}(\mathrm{NO})_{2}^{+}$. Formation of the dioxide species with elimination of $\mathrm{N}_{2}$, as observed with cobalt and rhodium clusters $[13,14,55]$, is not observed on the $\mathrm{Co}^{+}$ monomer in our experiment:

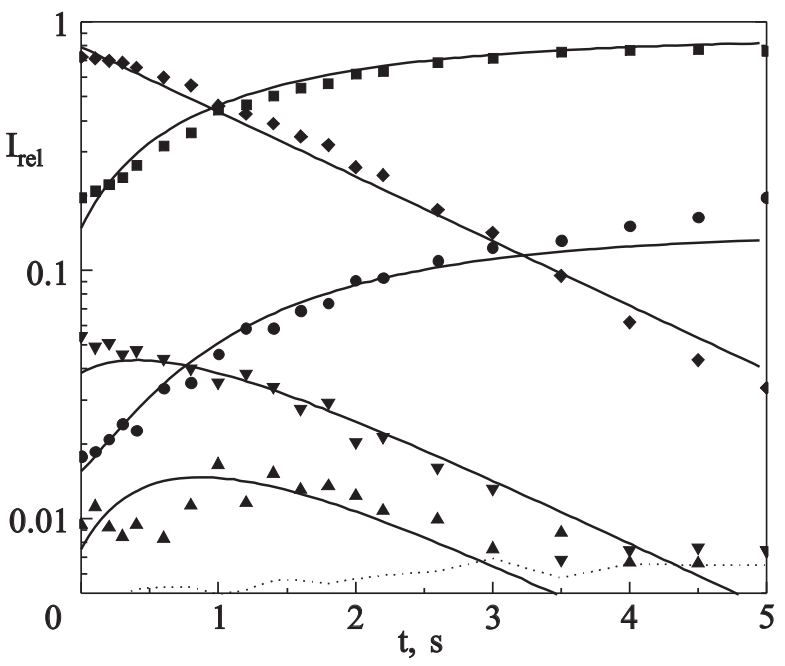

Fig. 3. Kinetics of the reaction of $\mathrm{CoAr}_{6}^{+}$and NO at an experimental pressure of $3.9 \cdot 10^{-8} \mathrm{mbar}$. The lines show the pseudo first order fits. $\mathrm{Co}(\mathrm{NO})^{+}(\boldsymbol{\bullet}) ; \mathrm{Co}(\mathrm{NO})_{2}^{+}(\bullet) ; \operatorname{CoAr}(\mathrm{NO})^{+}(\boldsymbol{\Delta})$; $\operatorname{CoAr}_{5}^{+}(\boldsymbol{\nabla}) ; \operatorname{CoAr}_{6}^{+}(\bullet)$; noise level $(\cdots)$. 


$$
\mathrm{CoAr}(\mathrm{NO})^{+}+\mathrm{NO} \longrightarrow \mathrm{Co}(\mathrm{NO})_{2}^{+}+\mathrm{Ar} .
$$

In case of dinitrogen monoxide $\mathrm{N}_{2} \mathrm{O}$ the reaction scheme is much more complicated, because there are a lot of products, as shown in the reaction kinetics in Fig. 4. The important primary reaction channel is the uptake of one $\mathrm{N}_{2} \mathrm{O}$ molecule in the cluster by losing two to five argon atoms:

$$
\mathrm{CoAr}_{6}^{+}+\mathrm{N}_{2} \mathrm{O} \longrightarrow \mathrm{CoAr}_{6-m}\left(\mathrm{~N}_{2} \mathrm{O}\right)^{+}+m \mathrm{Ar} ; m=2-5 .
$$

The mixed $\operatorname{CoAr}_{n}\left(\mathrm{~N}_{2} \mathrm{O}\right)^{+}$species may in principle lose argon atoms induced by black-body radiation, since the $\mathrm{Co}\left(\mathrm{N}_{2} \mathrm{O}\right)^{+}$unit is a strong infrared absorber. As long as there are argon atoms, the uptake of a second $\mathrm{N}_{2} \mathrm{O}$ molecule is observed. The pure $\operatorname{Co}\left(\mathrm{N}_{2} \mathrm{O}\right)^{+}$gets oxidized in a reaction with a second $\mathrm{N}_{2} \mathrm{O}$ molecule, forming $\mathrm{CoO}\left(\mathrm{N}_{2} \mathrm{O}\right)^{+}$. This oxidation is the typical reaction of metal atoms and clusters with $\mathrm{N}_{2} \mathrm{O}[12,14,56-58]$ :

$$
\begin{aligned}
& \mathrm{CoAr}_{m}\left(\mathrm{~N}_{2} \mathrm{O}\right)^{+}+\mathrm{N}_{2} \mathrm{O} \longrightarrow \mathrm{Co}\left(\mathrm{N}_{2} \mathrm{O}\right)_{2}^{+}+m \mathrm{Ar} ; m=1-4, \\
& \mathrm{Co}\left(\mathrm{N}_{2} \mathrm{O}\right)^{+}+\mathrm{N}_{2} \mathrm{O} \longrightarrow \mathrm{CoO}\left(\mathrm{N}_{2} \mathrm{O}\right)^{+}+\mathrm{N}_{2} .
\end{aligned}
$$

Nitrogen dioxide reacts with $\mathrm{CoAr}_{6}^{+}$under formation of the primary reaction products $\mathrm{CoAr}_{5}^{+}, \mathrm{CoAr}\left(\mathrm{NO}_{2}\right)^{+}$and $\mathrm{Co}\left(\mathrm{NO}_{2}\right)^{+}$:

$$
\begin{aligned}
& \mathrm{CoAr}_{6}^{+}+\mathrm{NO}_{2} \longrightarrow \mathrm{CoAr}_{6-m}\left(\mathrm{NO}_{2}\right)^{+}+m \mathrm{Ar} ; m=5,6, \\
& \mathrm{CoAr}_{6}^{+}+\mathrm{NO}_{2} \longrightarrow \mathrm{CoAr}_{5}^{+}+\mathrm{NO}_{2}+\mathrm{Ar} .
\end{aligned}
$$

The main reaction channel is definitely the formation of $\mathrm{CoAr}_{5}{ }^{+}$, which reacts to $\mathrm{Co}\left(\mathrm{NO}_{2}\right)^{+}$and $\mathrm{CoAr}\left(\mathrm{NO}_{2}\right)^{+}$with higher efficiency than $\mathrm{CoAr}_{6}^{+}$. There are also product clusters containing NO. Their intensity is consistent with an NO impurity of $10 \%$ in the UHV. In secondary reac-

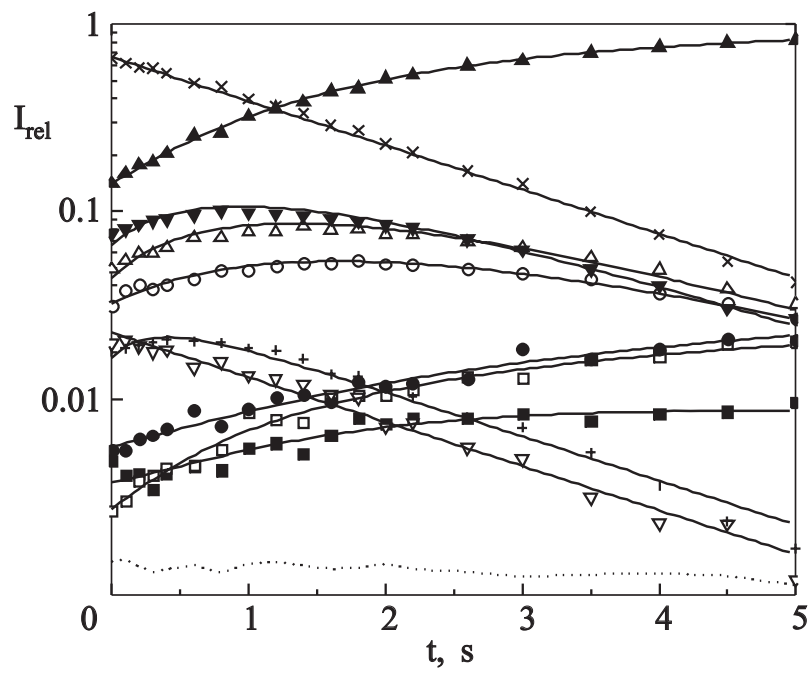

Fig. 4. Kinetics of the reaction of $\mathrm{CoAr}_{6}^{+}$and $\mathrm{N}_{2} \mathrm{O}$ at an experimental pressure of $2.0 \cdot 10^{-8}$ mbar. The lines show the pseudo first order fits. $\mathrm{Co}\left(\mathrm{N}_{2} \mathrm{O}\right)^{+}(\mathbf{\bullet}) ; \mathrm{CoO}\left(\mathrm{N}_{2} \mathrm{O}\right)^{+}(\square) ; \mathrm{Co}\left(\mathrm{H}_{2} \mathrm{O}\right)\left(\mathrm{N}_{2} \mathrm{O}\right)^{+}(\bullet)$; $\mathrm{Co}\left(\mathrm{N}_{2} \mathrm{O}\right)_{2}^{+}(\mathrm{O}) ; \quad \operatorname{CoAr}\left(\mathrm{N}_{2} \mathrm{O}\right)^{+}(\mathbf{\Delta}) ; \operatorname{CoAr}_{2}\left(\mathrm{~N}_{2} \mathrm{O}\right)^{+}(\triangle)$; $\mathrm{CoAr}_{3}\left(\mathrm{~N}_{2} \mathrm{O}\right)^{+}(\boldsymbol{\nabla}) ; \mathrm{CoAr}_{5}^{+}(\nabla) ; \operatorname{CoAr}_{4}\left(\mathrm{~N}_{2} \mathrm{O}\right)^{+}(+) ; \operatorname{CoAr}_{6}^{+}(\mathbf{X})$; noise level $(\cdots)$. tions, mixed species $\mathrm{Co}(\mathrm{NO})\left(\mathrm{NO}_{2}\right)^{+}$are observed. Interestingly, $\mathrm{CoNO}_{2}^{+}$undergoes a slow ligand exchange with $\mathrm{NO}$, indicating that $\mathrm{NO}$ is more strongly bound to $\mathrm{Co}^{+}$than $\mathrm{NO}_{2}$ :

$$
\begin{aligned}
& \mathrm{Co}\left(\mathrm{NO}_{2}\right)^{+}+\mathrm{NO} \longrightarrow \mathrm{Co}(\mathrm{NO})^{+}, \\
& \mathrm{CoAr}\left(\mathrm{NO}_{2}\right)^{+}+\mathrm{NO}_{2} \longrightarrow \mathrm{Co}\left(\mathrm{NO}_{2}\right)_{2}^{+}+\mathrm{Ar}, \\
& \mathrm{CoAr}\left(\mathrm{NO}_{2}\right)^{+}+\mathrm{NO} \longrightarrow \mathrm{Co}(\mathrm{NO})\left(\mathrm{NO}_{2}\right)^{+}+\mathrm{Ar} .
\end{aligned}
$$

This is nicely consistent with the observation that $\mathrm{CoAr}\left(\mathrm{NO}_{2}\right)^{+}$reaches a much higher intensity than $\mathrm{CoAr}(\mathrm{NO})^{+}$in the $\mathrm{NO}$ experiment. Water impurities are probably responsible for the formation of $\mathrm{Co}(\mathrm{OH})_{2}{ }^{+}$:

$$
\mathrm{Co}\left(\mathrm{NO}_{2}\right)^{+}+\mathrm{H}_{2} \mathrm{O} \longrightarrow \mathrm{Co}(\mathrm{OH})_{2}^{+}+\mathrm{NO}
$$

The corresponding kinetics are shown in Fig. 5.

The rate constant matrices used for fitting the data are shown in Tables 1-3, with the partial rates summed for each ion, and normalized so that the sum of the rates of $\mathrm{CoAr}_{6}^{+}$equals 1 . If the assumption that $\mathrm{CoAr}_{6}^{+}$reacts with collision rate is correct, the last row with the sums must contain only numbers less or equal 1 . However, some ions seem to react considerably faster than $\mathrm{CoAr}_{6}^{+}$, at odds with our assumption. Ar loss from $\operatorname{CoAr}_{m}\left(\mathrm{~N}_{2} \mathrm{O}\right)^{+}$ may be due to black-body radiation, since $\mathrm{N}_{2} \mathrm{O}$ attached to $\mathrm{Co}^{+}$becomes a potent low-frequency infrared absorber, so there is an explanation for a rate above collision rate. In case of $\mathrm{NO}$ and $\mathrm{N}_{2} \mathrm{O}$ the $\mathrm{CoAr}_{5}^{+}$gets only small intensities, so the fitted rate constants are not fully reliable. This does, however, not apply to $\mathrm{CoAr}_{5}^{+}$reacting with $\mathrm{NO}_{2}$. In this experiment, the intensity of $\mathrm{CoAr}_{5}^{+}$becomes high, and the rate constants extracted from the fit should be reliable. Probably $\mathrm{NO}_{2}$ cannot react directly with the fully coordinated cobalt. In the first step one argon atom is

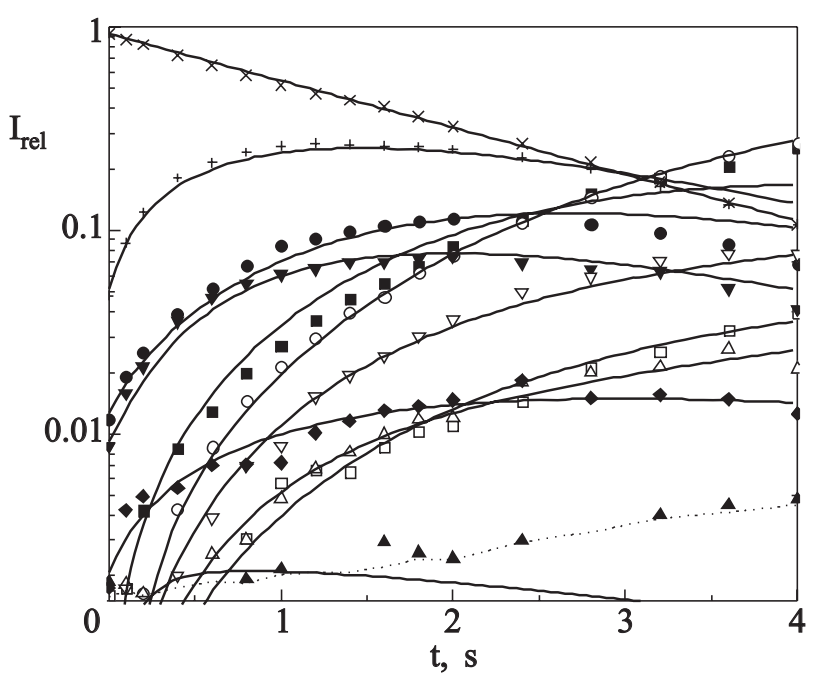

Fig. 5. Kinetics of the reaction of $\mathrm{CoAr}_{6}^{+}$and $\mathrm{NO}_{2}$ at an experimental pressure of $3.6 \cdot 10^{-8} \mathrm{mbar}$. The lines show the pseudo first order fits. $\mathrm{Co}(\mathrm{NO})^{+}(\mathbf{\bullet}) ; \mathrm{Co}(\mathrm{OH})_{2}^{+}(\square) ; \mathrm{Co}\left(\mathrm{NO}_{2}\right)^{+}(\bullet)$; $\mathrm{Co}(\mathrm{NO})_{2}^{+}(\mathrm{O}) ; \quad \mathrm{CoAr}(\mathrm{NO})^{+} \quad(\boldsymbol{\Delta}) ; \quad \mathrm{Co}(\mathrm{NO})\left(\mathrm{NO}_{2}\right)^{+} \quad(\triangle) ;$ $\mathrm{CoAr}\left(\mathrm{NO}_{2}\right)^{+}(\boldsymbol{\nabla}) ; \operatorname{Co}\left(\mathrm{NO}_{2}\right)_{2}^{+}(\nabla) ; \mathrm{CoAr}_{4}^{+}(\diamond) ; \mathrm{CoAr}_{5}^{+}(+) ;$ $\mathrm{CoAr}_{6}^{+}(\times)$; noise level $(\cdots)$. 
knocked out leading to the main primary product $\mathrm{CoAr}_{5}^{+}$. Now there is a free coordination site, and $\mathrm{CoAr}_{5}^{+}$is more likely to react with collision rate. Therefore the $\mathrm{CoAr}_{5}^{+}$ reaction rate was used for pressure correction.

Table 1. Rate constant matrix for NO. Column denotes the reactant, row the product ion. «—» means the reaction was not allowed in the fit procedure, 0.00 means the fit is best without the reaction. The rate constants are normalized to a sum of 1.00 for the reactions of (e) $\mathrm{CoAr}_{6}^{+}$

\begin{tabular}{cl|c|c|c|c|c}
\hline \hline & $\mathrm{NO}$ & (a) & (b) & (c) & (d) & (e) \\
\hline \hline (a) & $\mathrm{Co}(\mathrm{NO})^{+}$ & - & - & 0.00 & 1.00 & 0.81 \\
(b) & $\mathrm{Co}(\mathrm{NO})_{2}^{+}$ & - & - & 4.69 & - & - \\
(c) & $\mathrm{CoArNO}^{+}$ & - & - & - & 1.71 & 0.00 \\
(d) & $\mathrm{CoAr}_{5}^{+}$ & - & - & - & - & 0.19 \\
(e) & $\mathrm{CoAr}_{6}^{+}$ & - & - & - & - & - \\
\hline & Sum & $\mathbf{0 . 0 0}$ & $\mathbf{0 . 0 0}$ & $\mathbf{4 . 6 9}$ & $\mathbf{2 . 7 1}$ & $\mathbf{1 . 0 0}$ \\
\hline
\end{tabular}

The reaction products reveal interesting properties of the ions and their chemistry. The fully argon decorated $\mathrm{CoAr}_{6}^{+}$ion does not activate any of the reactant molecules. This is in line with our earlier observation that dehydrogenation of hydrocarbons is reduced if metal clusters are decorated with argon atoms [59-61]. Another interesting and valuable result is that collisions lead to loss of at most one argon atom, which shows that the collision energy in our experiment is small: It takes only $10 \mathrm{~kJ} / \mathrm{mol}$ to remove an $\mathrm{Ar}$ from $\mathrm{CoAr}_{6}^{+}$. At the same time, this finding suggests that our initial assumption may be wrong: There may be elastic or almost elastic collisions, which do not lead to a detectable reaction.

Dinitrogen monoxide is a gas with a low sticking coefficient. The new correction factor $K_{p}$ for the pressures $8 \cdot 10^{-9}$ mbar and $5 \cdot 10^{-9} \mathrm{mbar}$, as listed in Table 4 , is in the error limit of the empirical method of $25 \%$. Here $K_{p} \approx G / R_{x}$ is a well suited approximation for pressure correction. Nitrogen oxide and nitrogen dioxide are compared to $\mathrm{N}_{2} \mathrm{O}$ sticky gases and can be adsorbed on the sur-

Table 2. Rate constant matrix for $\mathrm{N}_{2} \mathrm{O}$. Column denotes the reactant, row the product ion. «— means the reaction was not allowed in the fit procedure, 0.00 means the fit is best without the reaction. The rate constants are normalized to a sum of 1.00 for the reactions of (j) $\mathrm{CoAr}_{6}^{+}$

\begin{tabular}{ll|c|c|c|c|c|c|c|c|c|c}
\hline \hline & \multicolumn{1}{c|}{$\mathrm{N}_{2} \mathrm{O}$} & (a) & (b) & (c) & (d) & (e) & (f) & (g) & (h) & (i) & (j) \\
\hline \hline (a) & $\mathrm{Co}\left(\mathrm{N}_{2} \mathrm{O}\right)^{+}$ & - & - & - & 0.00 & - & 0.00 & 0.04 & 0.00 & 0.00 & 0.00 \\
$(\mathrm{~b})$ & $\mathrm{Co}(\mathrm{NO})_{2}^{+}$ & 0.15 & - & - & 0.02 & 0.00 & 0.03 & 0.00 & - & 0.20 & - \\
$(\mathrm{c})$ & $\mathrm{Co}\left(\mathrm{H}_{2} \mathrm{O}\right)\left(\mathrm{N}_{2} \mathrm{O}\right)^{+}$ & - & - & - & 0.00 & 0.01 & 0.00 & 0.04 & - & 0.01 & - \\
$(\mathrm{d})$ & $\mathrm{CoAr}\left(\mathrm{N}_{2} \mathrm{O}\right)^{+}$ & - & - & - & - & - & 0.34 & 0.04 & 0.53 & 1.02 & 0.06 \\
$(\mathrm{e})$ & $\mathrm{Co}\left(\mathrm{N}_{2} \mathrm{O}\right)_{2}^{+}$ & - & - & - & 1.24 & - & 1.19 & 1.16 & - & 4.38 & - \\
$(\mathrm{f})$ & $\mathrm{CoAr}_{2}\left(\mathrm{~N}_{2} \mathrm{O}\right)^{+}$ & - & - & - & - & - & - & 0.47 & - & 0.00 & 0.27 \\
$(\mathrm{~g})$ & $\mathrm{CoAr}_{3}\left(\mathrm{~N}_{2} \mathrm{O}\right)^{+}$ & - & - & - & - & - & - & - & 0.39 & 0.00 & 0.45 \\
$(\mathrm{~h})$ & $\mathrm{CoAr}_{5}$ & - & - & - & - & - & - & - & - & - & 0.03 \\
$(\mathrm{i})$ & $\mathrm{CoAr}_{4}\left(\mathrm{~N}_{2} \mathrm{O}\right)^{+}$ & - & - & - & - & - & - & - & 0.99 & - & 0.19 \\
(j) & $\mathrm{CoAr}_{6}^{+}$ & - & - & - & - & - & - & - & - & - & - \\
\hline
\end{tabular}

Table 3. Rate constant matrix for $\mathrm{NO}_{2}$. Column denotes the reactant, row the product ion. «— means the reaction was not allowed in the fit procedure, 0.00 means the fit is best without the reaction. The rate constants are normalized to a sum of 1.00 for the reactions of $(\mathrm{k}) \mathrm{CoAr}_{6}^{+}$

\begin{tabular}{ll|c|c|c|c|c|c|c|c|c|c|c}
\hline \hline & $\mathrm{NO}_{2}$ & (a) & (b) & (c) & (d) & (e) & (f) & (g) & (h) & (i) & (j) & (k) \\
\hline \hline (a) & $\mathrm{Co}(\mathrm{NO})^{+}$ & - & - & 1.99 & - & 0.00 & - & 0.00 & 0.00 & 0.00 & 0.00 & 0.00 \\
$(\mathrm{~b})$ & $\mathrm{Co}(\mathrm{OH})_{2}^{+}$ & - & - & 0.19 & - & - & - & - & - & - & - & - \\
$(\mathrm{c})$ & $\mathrm{Co}\left(\mathrm{NO}_{2}\right)^{+}$ & - & - & - & - & - & - & 2.69 & - & - & 0.23 & 0.09 \\
$(\mathrm{~d})$ & $\mathrm{Co}(\mathrm{NO})_{2}^{+}$ & 1.14 & - & - & - & 9.84 & 2.93 & - & - & - & - & - \\
$(\mathrm{e})$ & $\mathrm{CoArNO}$ & - & - & - & - & - & - & - & - & 0.05 & 0.02 & 0.02 \\
$(\mathrm{f})$ & $\mathrm{Co}(\mathrm{NO})\left(\mathrm{NO}_{2}\right)^{+}$ & 0.01 & - & - & 0.24 & 0.00 & - & 0.41 & 0.00 & - & - & - \\
$(\mathrm{g})$ & $\mathrm{CoAr}\left(\mathrm{NO}_{2}\right)^{+}$ & - & - & - & - & - & - & - & - & 0.48 & 1.11 & 0.05 \\
$(\mathrm{~h})$ & $\mathrm{Co}\left(\mathrm{NO}_{2}\right)_{2}^{+}$ & - & - & - & - & - & - & 0.60 & - & - & - & - \\
$(\mathrm{i})$ & $\mathrm{CoAr}$ & - & - & - & - & - & - & - & - & - & 0.02 & 0.02 \\
$(\mathrm{j})$ & $\mathrm{CoAr}$ & - & - & - & - & - & - & - & - & - & - & 0.82 \\
$(\mathrm{k})$ & $\mathrm{CoAr}$ & - & - & - & - & - & - & - & - & - & - & - \\
\hline
\end{tabular}


Table 4. Calculation of the new correction factor $K_{p}$ for different experimental pressures, $K_{p}^{\text {spin }}$ under the assumption of spin selection rules, and comparison to the empirical method $G / R_{x}$

\begin{tabular}{|c|c|c|c|c|c|c|}
\hline Molecule & $k_{\mathrm{ADO}}, 10^{-10} \mathrm{~cm}^{3} / \mathrm{s}$ & $p^{\exp }$, mbar & $\sum k_{\mathrm{rel}}, \mathrm{s}^{-1}$ & $K_{p}$ & $K_{p}^{\mathrm{spin}}$ & $G / R_{x}$ \\
\hline $\mathrm{N}_{2} \mathrm{O}$ & 6.48 & $\begin{array}{l}2.0 \cdot 10^{-8} \\
8.0 \cdot 10^{-9} \\
5.0 \cdot 10^{-9}\end{array}$ & $\begin{array}{l}0.54 \\
0.22 \\
0.16 \\
\end{array}$ & $\begin{array}{l}1.73 \\
1.74 \\
2.04 \\
\end{array}$ & & 2.50 \\
\hline NO & 5.61 & $\begin{array}{l}3.9 \cdot 10^{-8} \\
1.3 \cdot 10^{-8} \\
8.5 \cdot 10^{-9} \\
5.6 \cdot 10^{-9}\end{array}$ & $\begin{array}{l}0.60 \\
0.21 \\
0.10 \\
0.05 \\
\end{array}$ & $\begin{array}{l}1.12 \\
1.20 \\
0.82 \\
0.70 \\
\end{array}$ & $\begin{array}{l}3.36 \\
3.60 \\
2.46 \\
2.10 \\
\end{array}$ & 3.85 \\
\hline $\mathrm{NO}_{2}$ & 6.51 & $\begin{array}{l}3.6 \cdot 10^{-8} \\
4.8 \cdot 10^{-9}\end{array}$ & $\begin{array}{l}0.74 \\
0.14\end{array}$ & $\begin{array}{l}1.28 \\
1.80\end{array}$ & $\begin{array}{l}3.84 \\
5.40\end{array}$ & 2.56 \\
\hline
\end{tabular}

faces. This is immediately evident in the handling of the gases in the UHV apparatus. If $\mathrm{N}_{2} \mathrm{O}$ is introduced and the needle valve closed again, the base pressure is reached within seconds. With $\mathrm{NO}$ and $\mathrm{NO}_{2}$, the situation is completely different. The pressure in the UHV region reacts only slowly on a reduced gas flow. If the needle valve is closed completely, the gas is pumped away very slowly, and the base pressure cannot be reached without baking out the system for several hours. The turbomolecular pump generates a pressure gradient from the pump via the ion gauge, which is mounted close to the pump, to the quite distant ICR cell. The needle valve is mounted in-between the ion gauge and the cell. For a sticky substance the pressure in the ICR cell must be considerably larger than the pressure measured by the ion gauge. The correction factor determined from the $\mathrm{CoAr}_{6}^{+}$experiment suggests the opposite. This is the third piece of evidence that the initial assumption is wrong.

The interaction energy of $\mathrm{NO}$ and $\mathrm{NO}_{2}$ with $\mathrm{Co}^{+}$is certainly larger than for $\mathrm{N}_{2} \mathrm{O}$ with $\mathrm{Co}^{+}$. Yet, $\mathrm{N}_{2} \mathrm{O}$ seems to react with collision rate, while the two radicals seem not to. This hints to the possibility that spin selection rules [62] are responsible for the reduced reactivity of $\mathrm{NO}$ and $\mathrm{NO}_{2}$, as previously observed for the reaction of hydrated electrons with $\mathrm{O}_{2}$ [7,63]. Given the triplet multiplicity of $\mathrm{CoAr}_{6}^{+}$, it is conceivable that only one out of the three possible relative orientations of the spin systems of the two reactants leads to a reaction. Consequently, only one out of three collisions will be reactive. Table 4 lists the correction factor $K_{p}^{\text {spin }}$ derived with this assumption, which seems to be more reasonable than $K_{p}$. For now, this mechanism is speculative. Further experiments, especially a comparison of $\mathrm{CoAr}^{+}$with, e.g., $\mathrm{AgAr}^{+}$reactivities, are needed to substantiate this idea.

\section{Conclusion}

A new pressure calibration method was tested to determine the absolute pressure in the ICR cell and using this pressure to get accurate rate constants. For sticky sub- stances like $\mathrm{NO}$ or $\mathrm{NO}_{2}$, the pressure dependence of the correction factor shows that it is essential to use a new pressure calibration method. However, the correction factor determined with $\mathrm{CoAr}_{6}^{+}$is most likely wrong, because two arguments indicate that $\mathrm{CoAr}_{6}^{+}$does not react with collision rate, at least with $\mathrm{NO}$ and $\mathrm{NO}_{2}$. The considerably higher total rates of secondary reaction products compared to $\mathrm{CoAr}_{6}^{+}$indicate that not every collision is reactive. The small collision energies make it seem plausible that unreactive collisions occur. Therefore, the correction factors determined in the present study are probably wrong. In the future, $\mathrm{CoAr}^{+}$or $\mathrm{CoAr}_{2}^{+}$should be tried. These ions offer open coordination sites, so that elastic scattering of the neutral reaction partner becomes very unlikely. The number of possible reaction pathways is strongly reduced. While $\mathrm{CoAr}^{+}$is smaller and offers the largest number of coordination sites, $\mathrm{CoAr}_{2}^{+}$has no dipole moment, so the ADO collision rate should be more reliable for this ion. If the problem persists, this would hint that spin selection rules are behind the presumably low efficiency of $\mathrm{CoAr}_{6}^{+}$ reacting with radicals. This question can be settled with argon complexes of metal ions in singlet ground state.

Financial support from the Deutsche Forschungsgemeinschaft and the Fonds der Chemischen Industrie is gratefully acknowledged.

1. R.L. Summers, NASA Report TN D-5285 (1969).

2. J.E. Bartmess and R.M. Georgiadis, Vacuum 33, 149 (1983).

3. M. Schulte, B. Schlosser, and W. Seidel, Fresenius J. Anal. Chem. 348, 778 (1994).

4. R. Holanda, NASA Report TN D-6815 (1972).

5. O.P. Balaj, I. Balteanu, B.S. Fox-Beyer, M.K. Beyer, and V.E. Bondybey, Angew. Chem. Int. Ed. 42, 5516 (2003).

6. O.P. Balaj, E.P.F. Lee, I. Balteanu, B.S. Fox, M.K. Beyer, J.M. Dyke, and V.E. Bondybey, Int. J. Mass Spectrom. 220, 331 (2002).

7. O.P. Balaj, C.K. Siu, I. Balteanu, M.K. Beyer, and V.E. Bondybey, Chem. Eur. J. 10, 4822 (2004).

8. O.P. Balaj, C.K. Siu, L. Balteanu, M.K. Beyer, and V.E. Bondybey, Int. J. Mass Spectrom. 238, 65 (2004). 
9. I. Balteanu, O.P. Balaj, B.S. Fox, M.K. Beyer, Z. Bastl, and V.E. Bondybey, Phys. Chem. Chem. Phys. 5, 1213 (2003).

10. M. Beyer, U. Achatz, C. Berg, S. Joos, G. Niedner-Schatteburg, and V.E. Bondybey, J. Phys. Chem. A103, 671 (1999).

11. Y. Cao, R.F. Höckendorf, and M.K. Beyer, Chem. Phys. Chem. 9, 1383 (2008).

12. O.P. Balaj, I. Balteanu, T.T.J. Roßteuscher, M.K. Beyer, and V.E. Bondybey, Angew. Chem. Int. Ed. 43, 6519 (2004).

13. M.L. Anderson, M.S. Ford, P.J. Derrick, T. Drewello, D.P. Woodruff, and S.R. Mackenzie, J. Phys. Chem. A110, 10992 (2006).

14. M.L. Anderson, A. Lacz, T. Drewello, P.J. Derrick, D.P. Woodruff, and S.R. Mackenzie, J. Chem. Phys. 130, 064305 (2009).

15. D. Harding, M.S. Ford, T.R. Walsh, and S.R. Mackenzie, Phys. Chem. Chem. Phys. 9, 2130 (2007).

16. D.J. Harding, T.A.A. Oliver, T.R. Walsh, T. Drewello, D.P. Woodruff, P.J. Derrick, and S.R. Mackenzie, Eur. J. Mass Spectrom. 15, 83 (2009).

17. K. Eller and H. Schwarz, Chem. Rev. 91, 1121 (1991).

18. S. Feyel, J. Döbler, R.F. Höckendorf, M.K. Beyer, J. Sauer, and H. Schwarz, Angew. Chem. Int. Ed. 47, 1946 (2008).

19. M. Ončák, Y.L. Cao, R.F. Höckendorf, M.K. Beyer, R. Zahradník, and H. Schwarz, Chem. Eur. J. 15, 8465 (2009).

20. D. Schröder and H. Schwarz, Angew. Chem. Int. Ed. 34, 1973 (1995).

21. D. Schröder, H. Schwarz, D.E. Clemmer, Y.M. Chen, P.B. Armentrout, V.I. Baranov, and D.K. Bohme, Int. J. Mass Spectrom. Ion Processes 161, 175 (1997).

22. T. Schindler, C. Berg, G. Niedner-Schatteburg, and V.E. Bondybey, Ber. Bunsen-Ges. Phys. Chem. 96, 1114 (1992).

23. T.A. Flaim and P.D. Ownby, J. Vac. Sci. Tech. 5, 661 (1971).

24. M. Beyer, C. Berg, G. Albert, U. Achatz, and V.E. Bondybey, Chem. Phys. Lett. 280, 459 (1997).

25. D. Lessen and P.J. Brucat, Chem. Phys. Lett. 149, 10 (1988).

26. L. Bass, T. Su, and M.T. Bowers, Int. J. Mass Spectrom. Ion Processes 28, 389 (1978).

27. L. Bass, T. Su, W.J. Chesnavich, and M.T. Bowers, Chem. Phys. Lett. 34, 119 (1975).

28. T. Su and M.T. Bowers, J. Chem. Phys. 58, 3027 (1973).

29. T. Su and M.T. Bowers, Int. J. Mass. Spectrom. Ion Phys. 12, 347 (1973).

30. T. Su, E.C.F. Su, and M.T. Bowers, J. Chem. Phys. 69, 2243 (1978).

31. P. Langevin, Ann. Chim. Phys. 5, 245 (1905).

32. M. Beyer, A. Lammers, E.V. Savchenko, G. Niedner-Schatteburg, and V.E. Bondybey, Phys. Chem. Chem. Phys. 1, 2213 (1999).

33. M. Beyer, E.V. Savchenko, G. Niedner-Schatteburg, and V.E. Bondybey, Fiz. Nizk. Temp. 25, 1087 (1999) [Low. Temp. Phys. 25, 814 (1999)].

34. M. Beyer, E.V. Savchenko, G. Niedner-Schatteburg, and V.E. Bondybey, J. Chem. Phys. 110, 11950 (1999).
35. M.K. Beyer, E.V. Savchenko, O.P. Balaj, I. Balteanu, B.S. Fox-Beyer, and V.E. Bondybey, Phys. Chem. Chem. Phys. 6, 1128 (2004).

36. M. Allemann, H. Kellerhals, and K.P. Wanczek, Int. J. Mass Spectrom. Ion Processes 46, 139 (1983).

37. P. Kofel, M. Allemann, H. Kellerhals, and K.P. Wanczek, Int. J. Mass Spectrom. Ion Processes 72, 53 (1986).

38. C. Berg, T. Schindler, G. Niedner-Schatteburg, and V.E. Bondybey, J. Chem. Phys. 102, 4870 (1995).

39. V.E. Bondybey and J.H. English, J. Chem. Phys. 74, 6978 (1981).

40. T.G. Dietz, M.A. Duncan, D.E. Powers, and R.E. Smalley, J. Chem. Phys. 74, 6511 (1981).

41. S. Maruyama, L.R. Anderson, and R.E. Smalley, Rev. Sci. Instrum. 61, 3686 (1990).

42. M.K. Beyer, Mass Spectrom. Rev. 26, 517 (2007).

43. R.C. Dunbar, Mass Spectrom. Rev. 23, 127 (2004).

44. R.C. Dunbar and T.B. McMahon, Science 279, 194 (1998).

45. B.S. Fox, M.K. Beyer, and V.E. Bondybey, J. Phys. Chem. A105, 6386 (2001).

46. E.N. Kitova, D.R. Bundle, and J.S. Klassen, J. Am. Chem. Soc. 124, 5902 (2002).

47. T. Schindler, C. Berg, G. Niedner-Schatteburg, and V.E. Bondybey, Chem. Phys. Lett. 250, 301 (1996).

48. P.D. Schnier, W.D. Price, R.A. Jockusch, and E.R. Williams, J. Am. Chem. Soc. 118, 7178 (1996).

49. M. Sena and J.M. Riveros, Rapid Commun. Mass Spectrom. 8, 1031 (1994).

50. D. Thölmann, D.S. Tonner, and T.B. McMahon, J. Phys. Chem. 98, 2002 (1994).

51. P. Weis, O. Hampe, S. Gilb, and M.M. Kappes, Chem. Phys. Lett. 321, 426 (2000).

52. M.J. Frisch, G.W. Trucks, H.B. Schlegel, G.E. Scuseria, M.A. Robb, J.R. Cheeseman, J.A. Montgomery, Jr., T. Vreven, K.N. Kudin, J.C. Burant, J.M. Millam, S.S. Iyengar, J. Tomasi, V. Barone, B. Mennucci, M. Cossi, G. Scalmani, N. Rega, G.A. Petersson, H. Nakatsuji, M. Hada, M. Ehara, K. Toyota, R. Fukuda, J. Hasegawa, M. Ishida, T. Nakajima, Y. Honda, O. Kitao, H. Nakai, M. Klene, X. Li, J.E. Knox, H.P. Hratchian, J.B. Cross, C. Adamo, J. Jaramillo, R. Gomperts, R.E. Stratmann, O. Yazyev, A.J. Austin, R. Cammi, C. Pomelli, J.W. Ochterski, P.Y. Ayala, K. Morokuma, G.A. Voth, P. Salvador, J.J. Dannenberg, V.G. Zakrzewski, S. Dapprich, A.D. Daniels, M.C. Strain, O. Farkas, D.K. Malick, A.D. Rabuck, K. Raghavachari, J.B. Foresman, J.V. Ortiz, Q. Cui, A.G. Baboul, S. Clifford, J. Cioslowski, B.B. Stefanov, G. Liu, A. Liashenko, P. Piskorz, I. Komaromi, R.L. Martin, D.J. Fox, T. Keith, M.A. Al-Laham, C.Y. Peng, A. Nanayakkara, M. Challacombe, P.M.W. Gill, B. Johnson, W. Chen, M.W. Wong, C. Gonzalez, and J.A. Pople, Gaussian 03, Revision B.01, Gaussian, Inc., Pittsburgh PA (2003).

53. G. Kummerlöwe and M.K. Beyer, Int. J. Mass Spectrom. 244, 84 (2005).

54. D.R. Lide, CRC Handbook of Chemistry and Physics, 75th ed., CRC Press, Boca Raton (1995). 
55. M.S. Ford, M.L. Anderson, M.P. Barrow, D.P. Woodruff, T. Drewello, P.J. Derrick, and S.R. Mackenzie, Phys. Chem. Chem. Phys. 7, 975 (2005).

56. M.M. Kappes and R.H. Staley, J. Am. Chem. Soc. 103, 1286 (1981).

57. M. Brönstrup, D. Schröder, I. Kretzschmar, H. Schwarz, and J.N. Harvey, J. Am. Chem. Soc. 123, 142 (2001).

58. I. Balteanu, O.P. Balaj, M.K. Beyer, and V.E. Bondybey, Phys. Chem. Chem. Phys. 6, 2910 (2004).

59. G. Albert, C. Berg, M. Beyer, U. Achatz, S. Joos, G. Niedner-Schatteburg, and V.E. Bondybey, Chem. Phys. Lett. 268, 235 (1997).
60. V.E. Bondybey and M.K. Beyer, J. Phys. Chem. A105, 951 (2001).

61. U. Achatz, M. Beyer, S. Joos, B.S. Fox, G. Niedner-Schatteburg, and V.E. Bondybey, J. Phys. Chem. A103, 8200 (1999).

62. H. Schwarz, Int. J. Mass Spectrom. 237, 75 (2004).

63. S.T. Arnold, R.A. Morris, A.A. Viggiano, and M.A. Johnson, J. Phys. Chem. 100, 2900 (1996). 